\title{
ROBERT HUTCHISON AT THE LONDON HOSPITAL CIRCA 1900 : REMINISCENCES OF A CLINICAL CLERK
}

\author{
BY \\ LANGLEY PORTER \\ San Francisco, California
}

As the twentieth century dawned, British medicine was in full flood of passage from the rather static nineteenth-century ideas based largely on Sydenham's views concerning 'the clinical entity', to take up more modern, more dynamic concepts which considered disease as a maladaptation of the organism to conditions of environment. These dynamic concepts were coming into medicine under the influence of the chemists who had already won over the biologists, microbiologists, and physiologists. These, in turn, were exerting an ever increasing influence on the pathologists and anatomists who were concentrating their studies more and more on function, and less exclusively on structure than they had done heretofore.

In those days, The London Hospital was an inspiring place in which students of medicine were brought under the influence of brilliant teachers, some clinging to the traditions of Sydenham and finding them satisfying, while others, a younger group, were struggling valiantly to deal with medicine as one field of biology. Of this forward looking group three were specially notable: Arthur Keith, William Bulloch, and Robert Hutchison. All three were vivid and vigorous persons, and all were deeply influenced by the biological approach of the German school of medicine. Nor must one overlook Henry' Head, Percy Dean, and Gilbert Schorstein. The views and enthusiasms of all these men were imparted to a remarkably competent junior staff, including Lewis Smith, Hugh Rigby, Dick Andrews, John Sherren, Ainley Walker, and many others, who carried the views of their seniors to clinical clerks and surgical dressers in unforgettable terms.

Early in the last year of the nineteenth century, there came to the old London a young Canadian, a neophyte in medicine, deeply aware of the inadequacies of his training and of the deficiencies of his cultural background. Thanks to Lewis Smith, then tutor in medicine at The London (who remained a lifelong friend), the neophyte found acceptance with his fellow students, and came to be known as the 'fat Yank' to distinguish him from the 'thin Yank', another and contemporary Canadian student. So it came about that the visitor spent two and a half happy and professionally profitable years in the Mile End Road. It was a time whose impress has been felt as inspiration in every one of the 50 years that have since elapsed.

Any attempt to recall the experiences of long gone days is apt to result in no more than inaccurate, misleading images; but even at this distance some of the old London memories are clear and sharply focussed, though the writer's relations with the teachers were never closer than that of clinical clerk to one of the honorary visiting physicians or student auditor to a lecturer. Among the best remembered of these are Keith, Bulloch, Leonard Hill, and Robert Hutchison. No less memorable are some student relations with Henry Head, Gilbert Schorstein, and Stephen McKenzie, all three masters of the teaching art. But it was Keith's instruction in anatomy, Bulloch's in bacteriology, and Hill's in physiology, that laid the foundation to what our fathers used to call 'the institutes of medicine', and prepared the student's mind to think constructively about the clinical material presented so satisfyingly by Robert Hutchison, Stephen McKenzie, and other clinicians.

Without any apparent conferences or adjustments of the curriculum, Hill, Bulloch, and Keith presented in a simplified way what are now known, at least in the United States, as preclinical subjects. There were neither duplications nor important omissions, and the courses were such that they left the student able to use the knowledge gained as a source of strength and enrichment for the understanding of the problems of clinical medicine; left him, too, able to understand and utilize the means by which medicine can solve these problems. In a way, this at the time, new teaching dynamic, with its emphases on optimum function as 'health' and on failures of function as ' disease', forced the older clinicians to reform their more static concepts about disease entities. Robert Hutchison needed to undertake no such reform, for he was an eloquent proponent of 
the values of functional physiology and pathology in the study and management of disease.

Across the years one sees the young Hutchison, tall and spare, austere of face, but the austerity lightened now and again by a rare but enlightening smile, revealing the innate kindliness of a just nature. To watch him examine an infant, especially one with pyloric obstruction, was an unforgettable lesson in clinical procedure. The gentleness, not only of his manipulations, but also in the spirit of his approach, made one feel that, without sentimentality, the man was alive with sympathy for the suffering child. His comments to the sister in charge were laconic, but so astute that after a very few questions and answers, the auditors, staff and students, had a complete history of what had happened to the baby. And his keen scrutiny of the infant, his emphasis on the need for patient, kind, time-consuming, visual observation in clinical examination was impressive. 'Use your eyes fully' was one of his axioms. The delicacy of his manoeuvres as he palpated and percussed the abdomen was something to be admired. And the final lesson, always stressed, was on the need to make every examination thorough and complete. Even in those cases where the lesion was obviously abdominal, he insisted that no one should neglect to examine the chest, the nervous system, and every other area of the child's body. He made his own demonstrations brilliant examples to the onlookers of what to do, and what not to do, in clinical examinations of the patient. And his discussions on such occasions, while short, were always exhaustive. As much time was given to the whys and wherefores of physical examination, as to the consideration of the disease under observation. It was his custom in those days to dwell on the advantages of an ability to prognose, and to emphasize the utility of prognosis in planning the details of a patient's regimen.

Often it seemed to his hearers that he was unduly optimistic in predicting the outcome of an illness, especially the illness of a baby with pyloric obstruction. But he was rarely wrong. As he would say, ' these infants seem to run downhill almost to the vanishing point, and then, in the hands of a careful, motherly nurse, begin a slow, steady improvement and finally get well.' That teaching, of course, was before Fredet devised, and Ramstedt adapted, the simple, now generally used, incision of the pyloric tumour.

Even to-day, however, the success of the operative procedure depends on preoperative and postoperative management of the patient, management that utilizes the same sort of close attention to the child's fluid and food needs as Robert Hutchison prescribed for his infant patients in those far-off days. It calls for the same sort of ability to predict on one day what the child will need on the next, and it demands also that the infant be provided with those psychological satisfactions that stem from kindliness and motherly understanding, things that were insisted on in all nursing services when Hutchison was clinician in charge.

Those days were before the time when motor cars drove out horses and the need for innumerable stables which served as breeding places for the housefly. These buzzing threats to infant life were everywhere, carrying infection from filth to food. As a result, wards and clinics were overrun with babies who suffered from 'second summer diarrhoeas', and from 'acute marasmus', the latter a state reflecting starvation and dehydration. These diarrhoea and acute marasmus cases raised the infant death rate appallingly, but the damage to children did not halt with them; for there were many who escaped death from acute seizures, but later became victims of a wide variety of malnutritional disorders of which rickets was one.

Poverty and ignorance, and the extent of habitual drunkenness of many East End parents of the early 1900 s, seem incredible to-day in the light of the vast social betterments that have since taken place. The neglected children of these parents, however, gave the students of medicine of that time opportunity to follow the natural history of disease in a way, and to a degree, impossible in this era of antibiotics and of immunization; gave them, too, the chance to observe the destructive results which follow a neglect of the nutritional needs of infants and expectant mothers. And out of such opportunities for observation, encouraged by such clinicians as Robert Hutchison, came new understandings that were to save many lives.

As the nineteenth century was passing into the twentieth, the major interest of those physicians who dealt with children was 'disease in childhood'. What is now known as preventive paediatrics had not as yet emerged as a field of specialization. Allergy, and the deficiency diseases, and the possibility of immunization were vaguely apprehended. The Germans were just beginning to write about balanced diets in terms of energy needs and caloric intake. The Americans were making life miserable for general practitioners by insisting that 'percentage' feeding formulas were essential for infants. These called for intricate mathematics in an impossible attempt to modify cow's milk into an exact replica of human mother's milk. The percentage feeders laboured under a handicap. The biologists of the time had not yet revealed the specificity of the proteins and fats of various animal species. 
At that period, Robert Hutchison, with Caledonian common sense, was preaching simplicity in feeding methods, and teaching that the infant's response is the only valid test of a feeding plan. One memory of his approach to this problem remains ineffaceable. In those Victorian days, the social conventions dictated that the controllers of the hospital should not expend charitable funds to provide food for patients. They were, however, authorized to buy medicines for the indigent. At that time there was a group of people so povertystricken that they could afford no better food than diluted, sweetened evaporated milk. The result of this feeding in terms of malnutrition and rickets was disastrous. Robert Hutchison overcame the difficulty by having the hospital provide free codliver oil. He ordered the parents to add a spare teaspoonful of the oil to each bottle feeding. The success was little short of sensational. The infants gained weight, turgor, and well-being, and came soon, most of them, to be as healthy a group of babies as the most exacting physician could hope to see.

At that time, also, American paediatricians, under the leadership of Emmett Holt, were convinced, and were teaching, that evaporated milk of any sort was an evil food, the source of scurvy and rickets, and scrupulously to be avoided. When Hutchison's experience with this foodstuff was later reported at a meeting of the American Pediatric Society, the report was received politely but dubiously. It was not more than a year or two after that the clinicians, Henry Heiman and Clifford Grulee, presented to the same Society reports lauding cod-liver oil as a preventive of rickets. Grulee had combined phosphorus with the oil he gave, and he showed radiographs of the patient's epiphyses to demonstrate the positive influence of cod-liver oil on calcium deposition.

John Howland of Baltimore, to whom paediatrics owes so much, rose with expressions of mild wrath to discuss these papers. 'I am tired,' he said, 'of hearing you clinicians who come here and talk nonsense. I am going back to my laboratory and show you up.' He went bàck, but his experiments only confirmed the clinicians, and led Howland to join forces with McCollum and Simmonds in researches that led to the first isolation of the fatsoluble vitamins.

The clinical acumen of Hutchison was such that it now seems, looking back, that he had premonitions of things to come. This shrewd estimation of the nutritive worth of cod-liver oil was only one: Long before the term ' allergy' was invented, and became, as it has, a diagnostic ' catchall', his students were learning from him that hives could result from the individual's idiosyncrasy for this or that food, and that the responsible food could be discovered by the use of an elimination dietary planned to exclude one item after another until the offending substance was found and abandoned. The role of insects in producing urticaria he knew and stressed. Papular urticaria (strophulus) was referred to 'poisoning, by biting fleas, haemorrhagic urticaria to outbreaks subsequent to bed bug bites.

While Hutchison's clinical methods were impressive and unforgettable, his kindly way with the anxious parents of distressed patients was an equally important part of the training his students got from him. No one, no matter how apparently degraded, received from him anything less than a full recognition of the dignity due to a man or woman as a human being. He was particularly sensitive to personality differences in children, which enabled him surely and quickly to arrive at a knowledge about a sick child, a knowledge that another clinician might discover only after time-consuming difficulty. This kindliness, which was without effusiveness, extended to his students. One illustration can be recalled across the years from a clinical clerk's experience. Late one night, soon after the Giemsa differential blood stain was introduced, a student, working up a case of pernicious anaemia, was bent over the microscope scrutinizing a Giemsa specimen. The young man looked up, and found Dr. Hutchison standing watching him work. The doctor asked and was told what was being examined. Then he took over the microscope, congratulated the student on the success of his staining, and spent some time discussing the appearances of the various cells, and of the techniques for making and staining blood smears; and he went on to talk about the, as yet unsolved, problems of pernicious anaemia. He left, urging the student not to abandon his interest in the study of blood. To this day there remains a vivid memory of that tall, spare figure as it disappeared through the doorway to enter the next ward. This was a trivial circumstance in the teaching routine of a senior staff member, in all likelihood forgotten within an hour or two, but it became a turning point in the professional career of the clinical clerk; a critical incident in a series of influential impressions that turned his major interest from surgery to medicine.

Hutchison's clinical sessions and his lectures were invariably enriched by references to the medical literature, German, French, and American, as well as British. These references, always apt to the discussion in hand, were thorough, without waste of time, constructively critical, and revealing an amazing industry in the study of current clinical and research journals. Such catholic interest in other men's work was far from common among teachers 
of those days, and Hutchison's demonstration of the utility and interest to be derived from keeping up with current writing was by no means the least of the lessons learned by those who were fortunate enough to hear this great teacher. For them such lessons would prove to be no less memorable aids to practice in future years, than the shrewd, thorough approaches to patients so characteristic of Robert Hutchison's teaching.

Gaiety is not one of the attributes that memory gives to Robert Hutchison. Unlike Henry Head, whose relations with his students had a touch of intimacy, Hutchison was invariably grave. On the other hand, Henry Head, teaching in the out-patient clinic, is remembered as the centre of a group, he sitting with an octopus-like multiple tube stethoscope fitted to his ears and to those of the students immediately round him, calling for reports from them of the impression of what they heard through the instrument. His comments were always gay or satirical. On one such occasion, discussing one of his favourite subjects, referred pain, the patient complained of a sharp ache in his heel. One student, Simey by name, ventured to suggest that this pain might be referred. 'Quite,' said Hëad, ' whence ?' Simey answered: 'From the kidney.' There was a moment's silence, then Head lapsed into a torrent of laughter: 'You're having me, Simey, you're having me.' No one could have expected such a clinical experience in a session with Robert Hutchison. He was never aloof, but always too occupied with the work in hand to give way to levity. In a discussion of a clinical evening he was memorable. A colleague would present his material, or a discussant would debate a point and resume his seat. The tall, long-muscled figure of Hutchison would rise slowly; it would seem to stretch upward like a telescope opening out. At his full height he would pause, stand silent for a moment, and then, with the utmost gravity pronounce: 'I am in profound disagreement with the last speaker.' Then he would proceed to make the sources of his disagreement clear, ruthlessly taking apart his opponent's argument, pointing out errors of fact, and in his concise Caledonian way, with unanswerable logic, build up his own thesis, leaving his audience edified and instructed.

In the dining room of The London Hospital of those days, there was one table at which the younger of the honorary staff met for luncheon. To be invited, on occasion, to sit at that table was a much relished honour, for the talk was rich in medical wisdom and humanist lore. Keith, Bulloch, Leonard Hill, and Hutchison were often at this table, and the discussions were never more entertaining or the conversation more sparkling than when they were present. On one such occasion, a rare one for the Canadian neophyte, he was fascinated to hear Robert Hutchison tell of his boyhood, heard him tell of it in his beautifully chosen English, spoken, then, with the slightest Scottish modulation. The story left the picture of a farmer's lad getting up long before day, while others of the family still slept, going to the oatmeal bin for the makings of porridge that he would boil up for himself. After he had eaten his oatmeal, and filled his pockets with oatcake, he would be on his way over the miles, four or more, that lay between his home and the school. When night came, the youngster would arrive at home long after dark to find the family all in bed and to repeat for dinner the routine of preparation that would provide the exact replica of the morning meal. To one conditioned to the relative luxury of a modest Canadian boyhood home, the fact that a young man could live through such years of austerity seemed no less than a miracle, and it was not less amazing that the boy who endured such a preparation for life could have become the eminent scholar, distinguished teacher, and kindly gentleman whose influence for good was daily moulding the thought and ethics of a host of young men, young men who, because of him, would carry a better, more human medicine into British homes and to many an outpost in far distant lands within and without the Commonwealth. 